Agata Matysiak-Błaszczyk

Uniwersytet im. Adama Mickiewicza w Poznaniu

Barbara Jankowiak

Uniwersytet im. Adama Mickiewicza w Poznaniu

\title{
Więzienne macierzyństwo kobiet z problemem alkoholowym
}

\section{Prison motherhood of women with an alcohol problem}

\begin{abstract}
Abstrakt
Macierzyństwo kobiet pozbawionych wolności jest ważnym problemem społecznym, gdyż dotyczy nie tylko samej osadzonej, ale także jej dzieci i całej rodziny oraz sposobu funkcjonowania w zakładzie karnym. Problem ten jest szczególnie trudny, gdyż dotyczy nie tylko osadzonych będących matkami, ale równocześnie matkami uzależnionymi od alkoholu. W tej sytuacji rośnie ilość czynników obciążających rozwój dziecka oraz wyzwań stawianych przed placówką resocjalizacyjną. Sposób oddziaływania pomocowego w więzieniu powinien uwzględniać zarówno dobro matki, jak i dziecka. Wyniki prowadzonych badań wskazują, że u kobiet inaczej niż u mężczyzn przebiega proces kontaktu ze środkami psychoaktywnymi oraz że istnieją różnice międzypłciowe w konsekwencjach używania i nadużywania środków psychoaktywnych. Problemy związane z używaniem alkoholu są powszechne wśród kobiet pozbawionych wolności, a uzależnionych skazanych matek przybywa w populacji przestępczych kobiet i dziewcząt. Podstawowymi celami oddziaływań pracowników Domów Matki i Dziecka jest kształtowanie u osadzonych kobiet pozostających w tym czasie w sytuacji aktywnego macierzyństwa umiejętności społecznych roli matki zarówno w czasie, gdy przebywają one wraz z potomstwem w warunkach izolacyjnych, jak i gdy opuszczą zakład karny. Istotne jest także zapewnienie ich dzieciom bezpieczeństwa i warunków umożliwiających prawidłowy rozwój psychospołeczny i fizyczny przy uwzględnieniu ograniczeń związanych ze specyfiką przebywania w placówce zamkniętej.
\end{abstract}

Słowa kluczowe: więzienie, macierzyństwo, uzależnienie, formy pomocy i wsparcia

\section{Wprowadzenie}

Problematyka używania i nadużywania substancji psychoaktywnych przez kobiety - matki odbywające karę pozbawienia wolności - nie jest znacząco eksplorowana zarówno w teorii, jak i badaniach naukowych. Dlatego też celem niniejszego artykułu jest ukazanie specyfiki macierzyństwa kobiet pozbawionych wolności doświadczających problemów alkoholowych, a także dylematów związanych z wychowywaniem dzieci w warunkach izolacji penitencjarnej. W ostatnich latach problemy związane z używaniem substancji psychoaktywnych przez kobiety nasilają się w skali i dynamice. Systematycznie wzrasta liczba nadmiernie pijących alkohol młodych kobiet i dziewcząt, a ich poziom picia (co do ilości i częstości spożywanego alkoholu) zbliża się do poziomu picia mężczyzn (Fudała, 2007). 
Jak podaje Małgorzata Dragan, nadmierne picie alkoholu przez kobiety należy traktować jako przedmiot szczególnej troski ze względu na stały wzrost konsumpcji alkoholu przez nie, szkodliwość picia kobiet będących w czasie ciąży, negatywne skutki picia alkoholu przez kobiety dla rozwoju dzieci w okresie prenatalnym oraz relacje między piciem i różnymi problemami z zakresu zdrowia prokreacyjnego kobiet. Alkohol w czasie ciąży może wpłynąć na rozwój płodu w sposób pośredni lub bezpośredni, upośledzając funkcjonowanie łożyska. Wzorzec intensywnego picia alkoholu i zaburzenia związane z jego używaniem wiążą się także ze współwystępowaniem zaburzeń psychicznych: depresji, zaburzenia po stresie traumatycznym, zaburzeń odżywiania i zachowań samobójczych. Autorka wskazuje, że kobiety nadużywające alkoholu lub od niego uzależnione zagrożone są w dużo większym stopniu doświadczaniem przemocy interpersonalnej, w tym seksualnej, a także podejmowaniem ryzykownych zachowań seksualnych (Dragan, 2016, s. 17-18). Z ostatnich danych Państwowej Agencji Rozwiązywania Problemów Alkoholowych wynika, że statystyczny Polak wypija 11 litrów czystego spirytusu na głowę, a jeszcze w roku 2005 było to 9,5 litra (Brzózka, 2019). Warto podkreślić, że proces kontaktu ze środkami psychoaktywnymi u dziewcząt i kobiet przebiega inaczej niż u chłopców, np. później dochodzi do inicjacji używania substancji, natomiast szybciej do uzależnienia, kobiety wykazują więcej problemów psychicznych związanych z używaniem substancji oraz gorzej reagują na leczenie, mają też większą skłonność do powrotu do użytkowania środków psychoaktywnych (Jankowiak, 2016, s. 313).

Pijące kobiety częściej niż mężczyźni doświadczają takich problemów jak: depresja, zaburzenia snu, zaburzenia lękowe, zaburzenia funkcji seksualnych. Niektóre panie alkoholem łagodzą objawy zespołu napięcia przedmiesiączkowego, sięgają po alkohol po zdarzeniach traumatycznych (Girczys-Połedniok, 2015, s. 50). Kobiece problemy alkoholowe są bardziej ukryte (jego ofiary upijają się najczęściej samotnie), są trudniejsze do diagnozowania i obciążone wieloma stereotypami (Zalikowska, 2009, s. 188). Nierzadko zdarza się, że kobiety uzależniają się krzyżowo, łącząc alkohol z lekami, najczęściej nasennymi i uspokajającymi (Pruchnik, 2016, s. 337).

W badaniach naukowych wyróżniono ścieżki rozwojowe dla nadużywania substancji, które równolegle dotyczyły rozwoju zachowań antyspołecznych od wczesnej młodości do dorosłości (Moffitt, 2010). Przykładem takiego podejścia są analizy Moffitt, która wyróżniła dwa rodzaje wzorów zachowań problemowych: trwały wzór życiowy i wzór ograniczony do adolescencji (Life-Course-Persisters, Adolescence-Limiteds). Moffitt i jej współpracownicy stwierdzili, że druga ścieżka, ograniczona do dojrzewania, jest bardziej charakterystyczna dla kobiet (Moffitt i Caspi, 2001). Korespondujące z cytowanymi danymi były longitunidalne badania nowozelandzkich dzieci (ich losy śledzono od urodzenia do 21. roku życia) prowadzone przez D.M. Fergussona i L.J. Horwooda, którzy stwierdzili, że kobiety częściej należały do grupy niskiego ryzyka przestępczości oraz grupy przestępczości ograniczonej do adolescencji (Fergusson i Horwood, 2002). Analizując przyczyny używania substancji psychoaktywnych przez kobiety (Andrews, 2005), cytuje badania, które wykazały związki między zachowaniami w dzieciństwie, takimi jak dziecięca agresja, niskie umiejętności społeczne z wczesną inicjacją 
używania substancji psychoaktywnych oraz ciężkim lub problemowym używaniem ich w okresie dojrzewania. Te czynniki również przewidują wzór całożyciowy Life-Course-Persisters zachowań antyspołecznych.

Zdaniem Andrews efekty stosowania substancji psychoaktywnych mogą się różnić ze względu na płeć. Te fizjologiczne różnice mogą przyczynić się do różnic płciowych w czasie między pierwszym użyciem alkoholu a nadużywaniem i uzależnieniem. Badania wskazują różnice płci w fizjologicznych efektach stosowania podobnych ilości alkoholu - kobiety, którym podano taką samą ilość etanolu jak mężczyznom, mają wyższy poziom alkoholu we krwi (co wynika między innymi z mniejszej procentowej zawartości wody w ich organizmie). Fizjologiczne różnice mogą powodować także poważne konsekwencje zdrowotne. Większość skutków zdrowotnych związanych z używaniem alkoholu przez młodzież występuje jednak w wieku dorosłym po długotrwałym stosowaniu. Dowody wskazują, że konsekwencje zdrowotne stosowania alkoholu mogą być bardziej szkodliwe dla kobiet niż mężczyzn oraz że istnieją takie konsekwencje, które są specyficzne dla kobiet. Andrews cytuje badania, z których wynika, że skutki spożycia alkoholu (na przykład marskość wątroby) mogą rozwinąć się szybciej u kobiet, stosowanie alkoholu wiąże się u nich także z niekorzystnymi wynikami sercowo-naczyniowymi oraz ryzykiem raka piersi. (Andrews, 2005, s. 181-211). Ponadto u kobiet częściej rozpoznaje się takie następstwa nadużywania alkoholu, jak alkoholowe uszkodzenie wątroby oraz szkody zdrowotne w zakresie układu sercowo-naczyniowego i mózgu, także wystąpienie zaburzeń w obrębie mięśni szkieletowych i kardiomiopatii. Kobiety uzależnione od alkoholu osiągają także gorsze wyniki testów psychomotorycznych i pamięci niż mężczyźni. Umieralność kobiet nadużywających alkoholu jest wyższa niż mężczyzn, przy czym główne jej przyczyny to: alkoholowe uszkodzenie wątroby, zapalenie trzustki, wypadki i przemoc, samobójstwa, nowotwory i choroby serca (http://www.parpa.pl/download/rozdzial03. pdf, data dostępu: 27.07.2015).

\section{Uzależnione od alkoholu kobiety w zakładach karnych}

Problemy związane z używaniem środków psychoaktywnych są wśród osób pozbawionych wolności na tyle rozpowszechnione, że zdaniem Andrzeja Majcherczyka każda większa jednostka penitencjarna powinna mieć własny oddział terapeutyczny dla skazanych uzależnionych. Niestety liczba tych oddziałów jest wciąż niewystarczająca. Jednocześnie w polskich warunkach penitencjarnych przy stale zwiększającej się liczbie osób uzależnionych coraz częściej stosuje się programy terapeutyczne w trakcie wykonywania kary pozbawienia wolności (Majcherczyk, 2007, s. 323).

Leczenie kobiet uzależnionych od alkoholu w zakładach karnych zostało wprowadzone później, aniżeli w przypadku skazanych mężczyzn. Pierwszy oddział dla uzależnionych kobiet został utworzony w 1976 roku w Grudziądzu i funkcjonuje do dnia dzisiejszego (Zalikowska, 2006, s. 189). Rehabilitacja skazanych kobiet uzależnionych od alkoholu zazwyczaj prowadzona jest w poradniach 
odwykowych działających przy wszystkich zakładach karnych (Marczak i Mirosław-Nawrocka, 2016, s. 181). Iwona Zalikowska wymienia kilka wspólnych właściwości kobiet alkoholiczek przebywających w warunkach izolacji penitencjarnej: wyraźny neurotyzm, wysoki poziom lęku przed otwieraniem się i to nie tylko warunkowany pobytem w izolacji, używanie siebie do zadowalania innych, używanie innych do określania swojej wartości oraz liczne ślady ciężkich traum przeżytych w dzieciństwie i młodości, rywalizacyjne kontakty z innymi kobietami i preferowanie płci przeciwnej. Picie kobiet szybciej prowadzi do destrukcji rodziny, a jednocześnie mechanizm wypierania choroby jest silniejszy, bo kobiety bronią pozycji dobrej matki i żony. Kobiety szybciej „przepijają” szacunek dla samych siebie i dlatego trudniej im odzyskać poczucie własnej wartości (Zalikowska, 2006, s. 189-190).

W aresztach śledczych i zakładach karnych przebywa 2760 kobiet, stanowią 3,7 procent populacji więziennej liczącej około 74 tysięcy osadzonych (Linder, 2017, s. 19). Z badań przeprowadzonych przez Janę Chojecką w trzech zakładach karnych dla kobiet (w Lublińcu, Krzywańcu i Grudziądzu) przy użyciu narzędzia LSI-R pozwalającemu na wyodrębnienie czterech kategorii skazanych kobiet ze względu na uzyskane wyniki na skali szacowania ryzyka powrotu do przestępstwa dowiadujemy się, że w kategorii średniego ryzyka recydywy stwierdzono symptomy ryzykownego picia bądź uzależnienia od alkoholu u blisko jednej trzeciej badanych, jedna dziesiąta zaś nadużywała substancji psychoaktywnych. Substancje (alkohol i narkotyki) przyczyniły się do popełnienia przestępstwa przez blisko jedną piątą badanych. W grupie o wyższym niż średnie ryzyku blisko trzy czwarte osadzonych miało problem z alkoholem, a blisko jedna trzecia z narkotykami. Substancje te w opinii trzech czwartych badanych przyczyniły się do naruszenia prawa - kradły, by mieć na alkohol lub narkotyki. W grupie o maksymalnym ryzyku powrotności do przestępstwa sześć na siedem badanych kobiet miało problem z alkoholem i narkotykami. U większości z nich można było stwierdzić nadużywanie obu tych substancji jednocześnie. Wszystkie respondentki wskazały, że łamały prawo w związku z uzależnieniem od substancji psychoaktywnych (Chojecka, 2013, s. 163). Z badań Agaty Matysiak-Błaszczyk wynika, że w przypadku kobiet pozbawionych wolności odbywających karę w zakładzie karnym w Krzywańcu w przypadku 25,8\% respondentek ojciec był uzależniony od alkoholu, a w przypadku 12,6\% uzależnienie dotyczyło matek (Matysiak-Błaszczyk, 2010). Wśród badanych kobiet $15,7 \%$ już w wieku szkolnym spożywało alkohol, a alkoholizm członków rodziny stał się przyczynkiem występowania w tych rodzinach problemu przestępczości. Spożywanie alkoholu przez ojców i matki badanych kobiet zdecydowanie zaburzyło prawidłowe funkcjonowanie rodzin. Zazwyczaj piciu towarzyszył brak pracy i zła sytuacja materialna rodzin. Ponadto $w$ rodzinach z problemem alkoholowym w badanej grupie wystąpił nieprawidłowy proces odgrywania ról społecznych u osób odpowiedzialnych za proces wychowawczy dzieci, często pozostawionych bez opieki, kontroli rodziców, niemających zaspokojonych podstawowych potrzeb egzystencjalnych. Wśród kobiet pozbawionych wolności uzależnionych od alkoholu najwyższe wyniki uzyskały respondentki, które przed karą pozbawienia wolności spożywały piwo $-72,3 \%$, wódkę - 49,5\%, wino - 29,7\%. Respondentki najczęściej piły we własnym domu 
- 45\% odpowiedzi; w tym miejscu warto podkreślić podwójne uzależnienie kobiet - od swoich partnerów, bardzo często alkoholików, i od alkoholu. Skazane kobiety problem alkoholowy często tłumaczą silnym oddziaływaniem mężczyzn na ich zachowania, tłumacząc się odczuwaniem obowiązku, przymusu picia z partnerem, dominacją jego władczej i dominującej pozycji w domu. Bywa i tak, że kobieta pije alkohol z partnerem dla zaznania świętego spokoju, z lęku przed awanturami domowymi albo dla towarzystwa. Skazane kobiety wychowywane w rodzinach z problemem alkoholowym zazwyczaj w dorosłym życiu wybierają partnera uzależnionego od środków psychoaktywnych, tym samym powielają one negatywne nawyki utrwalone $w$ toku socjalizacji pierwotnej. Negatywne doświadczenia przeżyte we wczesnym dzieciństwie znacząco wpływają na obraz kolejnych faz biograficznych (Matysiak-Błaszczyk, 2010, 2016a), prowadząc niejednokrotnie do szybkiej inicjacji alkoholowej. Tymczasem literatura konsekwentnie identyfikuje wczesną inicjację w używaniu substancji jako wskaźnik prognostyczny późniejszego problemu używania substancji psychoaktywnych i uzależnienia (Jankowiak, 2016, s. 315). Przykładowo - młodzi ludzie, którzy zaczynają pić przed 13 rokiem życia dwa razy częściej stają się alkoholikami niż ci, którzy zaczynają pić w wieku 17 lat i pięć razy częściej niż ci, którzy zaczynają pić w wieku 21 lat (Andrews, 2005). Czas pomiędzy wiekiem pierwszego użycia a uzależnieniem i nadużywaniem alkoholu może być krótszy dla dziewcząt niż chłopców (Lewinsohn, Rhode i Seeley, 1996, s. 375-390).

\section{Dylematy związane z macierzyństwem uzależnionych matek pozbawionych wolności}

Osadzone kobiety w polskich więzieniach $\mathrm{w}$ większości pełnią role macierzyńskie, wiele jest także uzależnionych od środków psychoaktywnych, w tym alkoholu. $Z$ analizy danych osób popełniających przestępstwa i trafiających do zakładu karnego celem odbycia kary pozbawienia wolności wynika, że wśród osób skazanych po raz pierwszy co najmniej $30 \%$ to osoby uzależnione od alkoholu, wśród recydywistów procent ten jest jeszcze wyższy. W etiologii przestępstw ponad $50 \%$ czynów karalnych popełnionych jest w związku z użyciem przez sprawców alkoholu (Szcześniak, 2016, s. 210). Uzależnienia to bardzo istotny, lecz także problemowy obszar oddziaływań resocjalizacyjnych, ponieważ uzależnionych skazanych matek przybywa w populacji przestępczych kobiet i dziewcząt, a liczba miejsc w oddziałach terapeutycznych jest stała. Zdarza się, że zanim zwolni się miejsce na oddziale terapeutycznym dla skazanej matki, to wcześniej wychodzi ona na przedterminowe zwolnienie lub kończy terminowo okres odbywania swojej kary. Same skazane niejednokrotnie mówią o tym, że dla nich walką z uzależnieniem jest izolacja. Dzięki izolacji nie mają możliwości stosowania środków psychoaktywnych (Matysiak-Błaszczyk, 2016a, s. 156-157).

Z narracji „więziennych" matek dowiadujemy się, że zarówno przed zajściem w ciążę, jak i w trakcie jej trwania, w zasadzie do czasu umieszczenia ich 
w zakładzie karnym nadużywały alkoholu. Konsekwencją ryzykownych zachowań kobiet jest występujący u większości dzieci alkoholowy zespół płodowy (FAS) czy alkoholowy efekt płodowy (FAE), który, jak wynika z literatury psychologicznej, dotyka wiele dzieci matek alkoholiczek (Matysiak-Błaszczyk, 2016a, s. 156-157). W Polsce w warunkach zakładów karnych występują poważne problemy z diagnozowaniem dzieci z podejrzeniem występowania FAS. Problemy te dotyczą nie tylko znikomej liczby specjalistów, którzy przeprowadzają pogłębione diagnozy, ale także długofalowego procesu leczenia i rehabilitacji. Innym ważnym problemem jest prowadzenie indywidualnych oddziaływań wychowawczych przeznaczonych dla dzieci z zespołem FAS. Wczesna diagnoza dzieci z zespołem FAS powinna być dobrą, powszechnie stosowaną praktyką, zwłaszcza wobec kobiet, u których występowały wskaźniki spożywania alkoholu przed ciążą i w czasie jej trwania (Matysiak-Błaszczyk, 2016a, s. 156-157).

Warto podkreślić, że ciężarne osadzone podlegają szczególnym procedurom w zakładzie karnym, aby mogły odpowiednio realizować funkcje opiekuńczo-wychowawcze. Osadzona ciężarna od momentu przybycia do placówki objęta jest wywiadami bezpośrednimi i pośrednimi, które umożliwiają przeprowadzenie diagnozy jej sytuacji życiowej. Kobiety ciężarne uzależnione od alkoholu przechodzą leczenie odwykowe na oddziale terapeutycznym (Matysiak-Błaszczyk, 2016b).

Przy zakładzie karnym w Grudziądzu od 1995 r. funkcjonuje oddział terapeutyczny ${ }^{1}$ z jedyną w Polsce placówką odwykową. Na leczenie do opisywanego oddziału przyjeżdżają skazane z całego kraju, ze wszystkich jednostek penitencjarnych: młodociane, pierwszy raz odbywające karę pozbawienia wolności, recydywistki, - łącznie około 100 rocznie (Zalikowska, 2009, s. 191). Według pani kierowniczki oddziału terapeutycznego najliczniejszą grupę stanowią skazane pierwszy raz odbywające karę pozbawienia wolności, zabójczynie, w przedziale wiekowym 30-45 lat. W ciągu kilkunastu lat istnienia oddziału trafiały tam najczęściej kobiety o niskim poziomie wykształcenia, około $70 \%$ stanowiły kobiety samotne lub z zachowanymi szczątkowymi relacjami rodzinnymi. Stosowały one środki psychoaktywne: tytoń (niemalże 100\% skazanych matek pali papierosy), piły alkohol, paliły marihuanę oraz używały innych narkotyków. Najczęściej stosowanym narkotykiem uzależniającym skazane kobiety-matki jest amfetamina wraz z heroiną i lekami psychotropowymi. Połowa składu

1 W systemie terapeutycznym karę pozbawienia wolności odbywają osoby uzależnione od alkoholu lub innych środków odurzających bądź psychotropowych (oprócz innych osób określonych przez ustawodawcę w art. 97, Ustawy z dnia 6 czerwca 1997 r. w kodeksie karnym wykonawczym). Osoby uzależnione wymagają specjalistycznego oddziaływania, a zwłaszcza opieki psychologicznej, lekarskiej lub rehabilitacji. Mogą odbywać karę pozbawienia wolności w systemie terapeutycznym, jeśli względy wychowawcze za tym przemawiają, a skazani wyrażą na to zgodę. Nadrzędnym celem systemu terapeutycznego jest zapobieganie pogłębianiu się patologicznego myślenia i działania tej kategorii przestępców oraz przywracanie im równowagi psychicznej. W systemie terapeutycznym skazana ma szansę na podjęcie leczenia, a oddziaływania terapeutyczne mogą zminimalizować dotychczas powstałe szkody fizyczne i psychiczne, jak również zapobiegać dalszej dysocjalności osoby skazanej. W terapii skazanego szczególną uwagę zwraca się na podnoszenie jego kompetencji społecznych. Skazanemu odbywającemu karę w systemie terapeutycznym sporządza się indywidualny program terapii, w którym określa się rodzaje i formy oddziaływań specjalistycznych oraz oddziaływania, które ujmowane są w systemie programowanego oddziaływania. 
społecznego kobiet pozbawionych wolności z problemem uzależnienia to osoby bezdomne, bez środków materialnych i finansowych. Nieliczne tylko mają zachowaną pełnię władzy rodzicielskiej. Niestety, jak wynika z doświadczeń pracowników oddziału terapeutycznego, większość kobiet podejmuje po raz pierwszy leczenie odwykowe w warunkach izolacji, będąc w chronicznym stadium uzależnienia od alkoholu. Prawie 100\% skazanych kobiet na tych oddziałach to ofiary przemocy domowej. Są to kobiety, które charakteryzują się poczuciem winy, wstydem, lękiem, cierpieniem. Jak twierdzi I. Zalikowska te cechy populacji skazanych kobiet wyznaczają w dużym stopniu sposób prowadzenia wobec nich oddziaływań terapeutycznych. Podejmowane oddziaływania powinny szczególnie kłaść nacisk na przeciwdziałanie powrotowi do zażywania substancji psychoaktywnych, z uwzględnieniem potrzeby korzystania w warunkach wolnościowych z pomocy psychiatrycznej.

Osadzone kobiety także w okresie odbywania kary pozbawienia wolności zostają matkami. Wobec nich podejmowane są oddziaływania resocjalizacyjne w Domu Matki i Dziecka, które dają im szanse na wprowadzenie pozytywnych zmian w ich społecznej biografii po opuszczeniu zakładu karnego (Matysiak-Błaszczyk, 2016a, s. 156-157). Znaczenie matki w procesie pierwotnej socjalizacji dziecka jest szczególne. Od matki oczekuje się między innymi ekspresji uczuć, serdeczności, ciepła, wyrozumiałości, tworzenia atmosfery emocjonalnej w rodzinie, zrozumienia, zaspokojenia potrzeb innych, wprowadzenia dziecka w krąg szerszej rodziny i tradycji (Grochocińska, 1992, s. 8). To w szczególności zachowania matki zapewniają dziecku bezpieczeństwo i budują poczucie przywiązania. Obecność matki w życiu dziecka ma niebagatelny wpływ na całokształt rozwoju psychicznego i fizycznego dziecka. Zdaniem Kazimierza Pospiszyla mimo naturalnego posłannictwa kobiety do roli macierzyńskiej trudno jest przewidzieć, jak takie macierzyństwo będzie przebiegało (Pospiszyl, 1978). Między dzieckiem i matką w pierwszych latach życia wytwarza się więź, która dzięki rozszerzaniu się zasobu doświadczeń sensoryczno-emocjonalnych w dalszej kolejności powoduje nasilenie związków emocjonalnych z ojcem, rodzeństwem, rówieśnikami i innymi osobami (Marczak, 2008, s. 458). Jakość więzi matki i dziecka jest bardzo istotna (Bidzan, 2013, s. 141). Często uważa się, że jest ona najtrwalszą więzią międzyludzką. Zdaniem M. Bidzan pierwotna więź matki i dziecka pojawia się w pierwszej kolejności jako wrodzona reakcja, mająca charakter autonomiczny, później powstają relacje emocjonalne dziecka z innymi ludźmi. Współcześnie pojęcie instynktu przekształciło się w pojęcie przywiązania czy też więzi (Brannon, 2002, s. 251). Więź oznacza łączność emocjonalną, która powstaje pomiędzy noworodkiem a opiekunem w ciągu pierwszych dni życia dziecka (Brannon, 2002, s. 251).

W początkowym okresie życie obejmującym niemowlęctwo, wiek poniemowlęcy i przedszkolny, rodzina, a w szczególności matka, odgrywa szczególnie ważną rolę w procesie socjalizacji dziecka. Według I. Wesołowskiej-Krzysztofek (1996) autentyczny, rzeczywisty i codziennie praktykowany kontakt osadzonych kobiet matek z ich dziećmi jest niezwykle korzystny dla nich samych i dzieci. Pozwala łatwiej znosić warunki izolacji poprzez nadanie dodatkowego, konkretnego, realnego celu, do którego mogą one dążyć, przy jednoczesnym umożliwieniu 
im samorealizacji w roli matek ${ }^{2}$. Autorka zakłada przy tym, iż pełnienie roli matki przez osadzone kobiety powoduje u nich wzrost poczucia przynależności, wzmaga uczucie akceptacji i miłości, która wymaga nawiązania bezpośrednich więzi między jej podmiotami, powoduje wykształcenie się kontaktów o niezwykle silnym ładunku emocjonalnym, sądząc przy tym, że skazane kobiety mogą rozpocząć proces analizy własnego dotychczasowego przestępczego życia i zrozumieć, że jego kontynuacja wyklucza w zasadzie osiąganie doświadczanie wartości życia rodzinnego, a jeśli było ono dotychczas pielęgnowane może zagrażać jego degradacją czy nawet destrukcją ${ }^{3}$.

Działanie matki w zakresie społecznego rozwoju dziecka dokonuje się za pośrednictwem modeli zachowania jej członków. Mogą to być zarówno wzory zgodnego współżycia i współdziałania, jak i modele sytuacji konfliktowych i działań aspołecznych. Funkcjonują one na zasadzie mechanizmu mimowolnego naśladownictwa, stanowiąc podstawę nabywania przez dziecko postaw i sposobu postępowania członków rodziny (Skorny, 1987, s. 59).

Zaznaczyć należy, że nie zawsze identyfikacja dziecka z rodzicami oparta na więzi z nimi jest wychowawczo korzystna. W rodzinach zdemoralizowanych, przestępczych dziecko, identyfikując się z rodzicami, przejmuje często wzory zachowań społecznie ujemnych. Karolina Kuryś opisuje macierzyństwo w kontekście nienormatywnych zdarzeń życiowych, które w literaturze nazywane są zdarzeniami zmiany życiowej, przełomami życiowymi oraz krytycznymi wydarzeniami życiowymi, które zaburzają dotychczasową równowagę między jednostką a otoczeniem, i wymagają wprowadzenia nowych, nieznanych dotąd sposobów radzenia sobie (Kuryś, 2010). Niewątpliwie sytuację izolacji kobiet w okresie ich aktywnego macierzyństwa można zaliczyć do sytuacji krytycznych wydarzeń życiowych piętnujących biograficznie kobiety i ich dzieci oraz wymagających szczególnych form wsparcia i pomocy.

Podstawowymi celami oddziaływań pracowników Domów Matki i Dziecka jest kształtowanie u osadzonych kobiet pozostających w tym czasie w sytuacji aktywnego macierzyństwa umiejętności społecznych roli matki, przynajmniej w czasie, gdy przebywają one wraz z potomstwem w warunkach izolacyjnych oraz zapewnienie ich dzieciom w tym czasie bezpieczeństwa i warunków do prawidłowego rozwoju psychospołecznego i fizycznego (Matysiak-Błaszczyk, 2016b).

Należy podkreślić, że sytuacja izolacji, w której skazane kobiety mają ograniczone, a niejednokrotnie zabronione kontakty fizyczne, społeczne i kulturowe z pierwotnym środowiskiem otwartym, nie jest standardowym środowiskiem socjalizacji dzieci. Zarówno kobiety, jak i ich dzieci przebywające w warunkach karnego ograniczenia wolności muszą podporządkować się panującemu w instytucji porządkowi w pełni skodyfikowanemu, wykonywać zalecenia personelu więziennego, a więc pozbyć się w znacznej mierze autonomii osobistej, ulegać przymusowi przebywania w otoczeniu innych skazanych, współtworzących specyficzne

2 Badania te przeprowadzone były w trzech jednostkach penitencjarnych (Grudziądz, Krzywaniec, Lubliniec) w 1992 roku na grupie 68 skazanych kobiet, patrz: Wesołowska-Krzysztofek, 1996, s. $470-480$.

3 Szerzej na ten temat: Muszyńska, 1976, s. 362-363. 
środowisko społeczne kobiet przestępczych i codziennych, więziennych realiach. Taka sytuacja może i niewątpliwie naraża ulokowane w niej dzieci na stygmatyzację i syndrom prizonizacji (Gajdus i Gronowska, 1999).

Ważnym aspektem pracy ze skazanymi matkami jest kształtowanie i utrwalanie właściwych postaw rodzicielskich. Jednak uzależnienie skazanych matek nie ułatwia procesu resocjalizacji, jest czynnikiem utrudniającym proces readaptacji społecznej oraz często sprzyja powrotowi do popełniania przestępstw. Beata Skafiriak stwierdza, że „więzienne” matki w warunkach izolacyjnych przejawiają postawy „taktycznego macierzyństwa”, a po opuszczeniu bram więzienia powracają do niekompetentnego wypełniania ról macierzyńskich, w tym także powrotu do nadużywania alkoholu i narkotyków. Z badań B. Skafiriak wynika, że skazane matki sprawują pieczę, a faktycznie socjalizują więzienne dzieci, przekazując im wzory zachowań nieodpowiadające standardowym wzorom funkcjonowania rodziny (Skafiriak, 2016, s. 425-427). Autorka wskazuje, że $81 \%$ skazanych kobiet $z$ więziennego domu matki i dziecka nie pozostawało w związku małżeńskim; 56\% skazanych matek to kobiety, które nie pozostawały w związku małżeńskim oraz miały więzienne dziecko i dzieci pozawięzienne, 25\% pozostawało w związku małżeńskim i miały tylko jedno dziecko, które pozostawało z nimi w więziennym Domu Matki i Dziecka w Zakładzie Karnym w Krzywańcu, u 66\% skazanych kobiet więziennych matek stwierdzono dysfunkcjonalność macierzyńską skazanej kobiety matki przed pobytem w zakładzie karnych wobec posiadanych dzieci. Autorka badań stwierdza, że na dziesięć skazanych kobiet matek przebywających w więziennym domu matki i dziecka tylko trzy z nich uzewnętrzniały funkcjonalną postawę macierzyńską wobec dziecka. W przypadku $82 \%$ skazanych kobiet stwierdzono dysfunkcjonalność środowiska rodziny pochodzenia. Zatem zdaniem B. Skafiriak więzienne matki w fazie aktywnego macierzyństwa nie mają utrwalonych kompetencji do pełnienia roli macierzyńskiej wg oczekiwań standardowych, bo ich matki takich wzorów im nie przekazały. Większość skazanych kobiet matek z Domu Matki i Dziecka w Zakładzie Karnym w Krzywańcu to córki matek ujawniających zjawiskowe formy patologii społecznej, dysfunkcjonalność macierzyńską, które zwłaszcza wędrowały od partnera do partnera, były uzależnione od alkoholu, zaniedbywały swoje obowiązki wobec dzieci. Więzienne matki, które były wychowywane w warunkach kulturowo zaniedbanych, posługują się wzorami komunikacji i kodem zachowań swojego środowiska i właśnie taki kapitał kulturowy (wiedzę, umiejętności i zachowanie) przekazują swojemu dziecku we wczesnej fazie jego procesu socjalizacji, przy tym jeszcze dokonywującego się w kontekście sytuacji życiowej skazanej matki w warunkach jej izolacji więziennej. Z badań B. Skafiriak wynika także, że niektóre kobiety urodziły dzieci intencjonalnie, by złagodzić sobie rygor sytuacji więziennej. Były poza tym kobiety, które zachodziły w ciążę w czasie odbywania kary bezwzględnego pozbawienia wolności. Z badań wynika także, że $60 \%$ kobiet porzuca swoje dzieci, czyli były to kobiety bez dalszej identyfikacji ze swoim dzieckiem. Dlatego znaczny odsetek dzieci po opuszczeniu zakładu karnego rozpoczyna swoją biografię w zastępczej rodzinie lub rodzinie pochodzenia matki, która już przecież niepomyślnie zsocjalizowała jednostkę ludzką, bądź innej formie opieki całkowitej poprzez ośrodki socjalizacyjne, resocjalizacyjne, zakład 
poprawczy, kończąc na pobycie w zakładzie karnym. W przypadku 93\% skazanych kobiet stwierdzono przejawy patologii w zachowaniu, a tylko $7 \%$ populacji stanowiły kobiety niezdemoralizowane, które popełniły przestępstwo sytuacyjnie i one nie wymagały resocjalizacji. Badaczka stwierdza, że

model roli macierzyńskiej najczęściej jest odtwarzany z rodziny pochodzenia, a brak u kobiety prawidłowego wzorca roli matki wpływa na obniżenie poziomu jej przystosowania (lub jej brak) do macierzyńskiej aktywności. Odnosi się to zwłaszcza do kobiet o niskim stopniu uspołecznienia, które przejawiają powrotność do przestępstwa, niestałość w roli pracownika, nieodpowiednie postawy wobec prawa, społeczności, dominujące zainteresowanie sobą, niski poziom moralny, nieodpowiednie postawy wobec małżeństwa i macierzyństwa (Skafiriak, 2016, s. 425-427).

Tęsknota i miłość to częste uczucia towarzyszące uwięzionym kobietom. I. Muszyńska podaje, że dla kobiet najgorszą sytuacją, z jaką muszą się zmagać w warunkach izolacji więziennej, jest rozłąka z najbliższymi, szczególnie dziećmi: „Ich związek z rodziną, z mężem, z dziećmi lub innymi osobami najbliższymi jest zwykle bardzo silny i bardzo emocjonalny. Zdecydowanie gorzej niż mężczyźni znoszą izolację więzienną" (Machel, 2002, s. 269).

Warto podkreślić, że małe dzieci pierwsze kontakty społeczne nawiązują z matką, ojcem, rodzeństwem oraz innymi domownikami (Skorny, 1987, s. 57). W przypadku dzieci przebywających wraz z matkami w zakładach karnych będą to inne osadzone i personel zakładu karego. Wczesna faza akulturacji polega na prostych przystosowaniach zachowania w sytuacjach kulturowo i społecznie uregulowanych do zachowań dzieci starszych i dorosłych. Z tymi elementarnymi doświadczeniami, opanowawszy mowę i chód, dziecko wchodzi w środowisko sąsiedzkie i przedszkolne. Nawiązuje kontakty z dziećmi i dorosłymi. Włącza się do zabawowych grup rówieśniczych, podejmuje czynne role w zabawie lub pełni rolę kibica w zabawach dzieci starszych. Uczestnicząc z życiu przedszkola, wchodzi do jego formalnych i nieformalnych grup dziecięcych, podejmując w nich role realne jak i fikcyjne. Uczestnicząc w tych rozszerzonych kręgach społecznych, dziecko uzupełnia i pogłębia wcześniejsze doświadczenia zdobyte we własnej rodzinie. Dziecko w tym okresie odzwierciedla podstawowe wartości i formy współżycia subkultury, w której wzrasta. Najistotniejszym osiągnięciem tego wieku jest wszakże odkrycie siebie w doświadczeniach z grupą, siebie jako „ja” społecznego - własnej jaźni subiektywnej (Znaniecki, 1973). Dlatego też na terenie Domów Matki i Dziecka powinny funkcjonować grupy przedszkolne, w celu zapewnienia dzieciom prawidłowego rozwoju psychofizycznego. Zwiększa to szansę adaptacji do warunków wolnościowych, a matkom ułatwiłyby możliwość podjęcia odpłatnej pracy. Ważnym wyzwaniem, jakie stoi przed kadrą penitencjarną, jest bowiem przygotowanie kobiet do opuszczenia zakładu karnego i podjęcia zadań macierzyńskich w warunkach wolnościowych (Matysiak-Błaszczyk, 2016b).

Ważnym elementem interwencji psychologiczno-pedagogicznych w Domach Matki i Dziecka powinny być także zajęcia edukacyjne i terapeutyczne o tematyce przeciwalkoholowej i przeciwprzemocowej, poradnictwo prawne i psychologiczne. Natomiast ważnym aspektem oddziaływań wychowawczych - motywowanie skazanych matek do utrzymywania i utrwalania związków rodzinnych (Matysiak-Błaszczyk, 2016b). 
Kobiety skazane z problemem alkoholowym mają możliwość uczestniczenia w cyklicznych spotkaniach grupowych lub indywidualnych z psychologiem pracującym na oddziale penitencjarnym. Uzależnione skazane matki mogą też brać udział w mitingach Anonimowych Alkoholików (AA) organizowanych na terenie zakładu karnego. Na terenie zakładu karnego prowadzone są również zajęcia psychoedukacyjne i psychoterapeutyczne mające na celu poznanie mechanizmów uzależnienia i współuzależnienia od alkoholu i narkotyków. Terapia indywidualna ze skazanymi matkami polega na omawianiu wybranych problemów psychologicznych i wychowawczych matek poprzez: spotkania indywidualne, czytanie literatury na tematy związane z uzależnieniem, uczestniczenie w zajęciach grupowych, mitingach AA oraz pisanie przez kobiety prac na tematy dotyczące ich uzależnienia (Matysiak-Błaszczyk, 2016a, s. 156-157).

Zdaniem H. Reczek macierzyństwo zmienia każdą kobietę, także tę, która przebywa za więziennymi murami, dla wielu skazanych kobiet dziecko staje się najważniejsze (Reczek, 2009, s. 225). Dla wielu matek więźniarek pobyt w instytucji Domu Matki i Dziecka ma wyraźny sens. Skazane w trakcie odbywania kary pozbawienia wolności wraz ze swoim dzieckiem uczą się rozpoznawać uczucia swoje i innych, nabierają umiejętności związanych z organizacją domu, w którym istnieje miłość i szacunek. U. Nowak dodaje, że więzienne Domy Matki i Dziecka są ratunkiem dla wszystkich dzieci, którym grozi oddanie do domu dziecka i choroba sieroca. Los przebywającego w placówce opiekuńczo-wychowawczej oderwanego od matki dziecka więźniarki jest szczególnie bolesny, bowiem ani nie może ono zostać adoptowane, ani nie spotyka się z matką. Autorka stwierdza, że resocjalizacja przez miłość jest skuteczna, jednak dodaje, że nikt nie twierdzi, że pobyt dziecka w więzieniu jest dla niego najlepszym rozwiązaniem.

Większość osadzonych kobiet uzależnionych od alkoholu pełni role macierzyńskie, część z nich wychowuje dzieci w warunkach izolacji penitencjarnej. Sytuacja ta stanowi ważne wyzwanie dla systemu resocjalizacji, zarówno ze względu na kwestię macierzyństwa skazanych, jak i ich problemu związanego z uzależnieniem. Podstawową kwestią jest leczenie uzależnionych kobiet oraz wspieranie ich w wytrwaniu w trzeźwości. Ponadto dylematy dotyczą kontaktów matki z dziećmi pozostającymi poza systemem izolacji, kobiet w ciąży, a także kobiet wychowujących dzieci w więzieniach. $Z$ jednej strony ustalenia z zakresu psychologii i pedagogiki jasno wskazują, że więź dziecka z matką jest niezwykle istotna dla jego prawidłowego rozwoju. Z drugiej strony dzieci w warunkach izolacji socjalizują się poprzez kontakt ze specyficznymi modelami funkcjonowania społecznego - osadzonych i personelu więziennego. Nadal brakuje badań naukowych dotyczących efektów takiej socjalizacji oraz losów życiowych matek i dzieci, które opuściły zakłady karne. Podsumowując, szczególnie istotne wydają się trzy kwestie. Po pierwsze, rozwijanie możliwości terapii uzależnień w trakcie i po odbyciu kary pozbawienia wolności przez kobiety. Po drugie, dostosowanie rozwiązań penitencjarnych do potrzeb matek i ich dzieci oraz zapewnienie pomocy po opuszczeniu przez nie zakładu karnego. Po trzecie, prowadzenie badań naukowych nad konsekwencjami wczesnej socjalizacji dzieci w warunkach izolacji penitencjarnej. 


\section{Bibliografia}

Adams G.R. (2005), Adolescent development, [w:] T.P. Gullotta (red.), Handbook of adolescent behavioral problems. Evidence-based approaches to prevention and treatment, G.R. Adams, New York, s. 3-16.

Andershed A.K. (2013), Girls at risk in their own right, [w:] A.K. Andershed (red.), Girls at risk. Swedish longitudinal research on adjustment, Springer, New York, s. 1-8.

Andrews J.A. (2005), Substance abuse in girls, [w:] D.J. Bell, S.L. Foster, E.J. Mash (red.), Handbook of behavioral and emotional problems in girls, Springer, New York, s. 181-209.

Bell D.J., Foster S.L., Mash E.J. (2005), Understanding behavioral and emotional problems in girls, [w:] D.J. Bell, S.L. Foster, E.J. Mash (red.), Handbook of behavioral and emotional problems in girls, Springer, New York, s. 1-24.

Bidzan M. (2013), Nastoletnie rodzicielstwo. Perspektywa psychologiczna, Harmonia Universalis, Gdańsk.

Brannon L. (2002), Psychologia rodzaju, Gdańskie Wydawnictwo Psychologiczne, Gdańsk.

Brzózka A. (2019), Alkoholizm w Polsce, „Newsweek”, www.newsweek.pl (data dostępu: 5.05.2019).

Chen X., Fu R., Leng L. (2014), Culture and developmental psychopathology, [w:] M. Lewis, K.D. Rudolph (red.), Handbook of developmental psychopathology, Springer, New York, s. 225-241.

Chojecka J. (2013), Kobieta w więzieniu i jej resocjalizacja - zamierzenia a rzeczywistość, Wydawnictwo Naukowe UAM, Poznań.

Dennis M.L., White M.K., Ives M.L. (2009), Individual characteristics and needs associated with substance misuse of adolescents and young adults in addiction treatment, [w:] C.G. Leukefeld, T.P. Gullotta, M. Staton-Tindall (red.), Adolescent substance abuse evidence-based approaches to prevention and treatment, Springer, New York, s. 45-72.

Dragan M. (2016), Problemowe picie alkoholu przez młode kobiety. Rola niekorzystnych doświadczeń i samoregulacji emocji, SCHOLAR, Warszawa.

Fergusson D.M., Horwood L.J. (2002), Male and female offending trajectories, „Development and Psychopathology" 14(1), s. 159-177.

Flannery D.J., Hussey D., Jefferis E. (2005), Adolescent delinquency and violent behavior, [w:] T.P. Gullotta, G.R. Adams (red.), Handbook of adolescent behavioral problems. Evidence-based approaches to prevention and treatment, Springer, New York, s. 415-438.

Fudała J. (2007), Kobiety i alkohol, Parpamedia, Warszawa.

Gajdus D., Gronowska B. (1999), Europejskie standardy traktowania więźniów, TNOiK, Toruń.

Grochocińska R. (1992), Życie dziecka w warunkach tymczasowej i stałej separacji matki i ojca, Wydawnictwo Uniwersytetu Gdańskiego, Gdańsk.

Jankowiak B. (2016), Używanie i nadużywanie substancji psychoaktywnych przez dziewczęta w okresie adolescencji, [w:] B. Jankowiak, A. Matysiak-Błaszczyk (red.), Kontrowersje wokół socjalizacji dziewcząt $i$ kobiet, Wydawnictwo Naukowe UAM, Poznań, s. 313-330.

Jarzębowska-Baziak B. (1987), Problem macierzyństwa w zakładzie karnym, [w:] T. Szymanowski, A. Rzepiński (red.), Doświadczenia i perspektywy systemu penitencjarnego w Polsce. Materiały ogólnopolskiej konferencji zorganizowanej w dniach 12-13 grudnia 1985 roku, Warszawa, s. 246.

Kuryś K. (2010), Urodzenie pierwszego dziecka jako krytyczne wydarzenie w życiu kobiet i mężczyzn, Impuls, Kraków.

Lewinsohn P.M., Rhode P., Seeley J.R. (1996), Alcohol consumption in high school adolescents. Frequency of use and dimensional structure of associated problems, „Addiction” 91, s. 375-390.

Linder G. (2017), Izolowane, „Forum Penitencjarne” 230, s. 19.

Machel H. (2003), Więzienie jako instytucja karna i resocjalizacyjna, Wydawnictwo Uniwersytetu Gdańskiego, Gdańsk.

Majcherczyk A. (2007), Specyfika terapii uzależnienia od środków psychoaktywnych w zakładach karnych, „Alkoholizm i Narkomania” 20(3), s. 321-342.

Marczak M. (2008), Pełnienie roli matki przez kobiety pozbawione wolności, [w:] W. Ambrozik, H. Machel, P. Stępniak (red.), Misja Służby Więziennej a jej zadania wobec aktualnej polityki karnej i oczekiwań społecznych IV Polski Kongres Penitencjarny. Poznań-Gdańsk-Warszawa, s. 457-466. 
Marczak M., Mirosław-Nawrocka K. (2016), Zakłady penitencjarne dla kobiet, [w:] M. Ciosek, B. Pastwa-Wojciechowska (red.), Psychologia penitencjarna, Wydawnictwo Naukowe PWN, Warszawa, s. 173-199.

Matysiak-Błaszczyk A. (2010), Sytuacja życiowa kobiet pozbawionych wolności, Impuls, Kraków.

Matysiak-Błaszczyk A. (2016a), Więzienne macierzyństwo. Studium socjopedagogiczne, Wydawnictwo Naukowe UAM, Poznań.

Matysiak-Błaszczyk A. (2016b), Macierzyństwo w izolacji - kontrowersje, wyzwania, dylematy, [w:] A. Matysiak-Błaszczyk, B. Jankowiak (red.), Kontrowersje wokół socjalizacji dziewcząt $i$ kobiet, Wydawnictwo Naukowe UAM, Poznań, s. 65-83.

Moffitt T.E., Caspi A. (2001), Childhood predictors differentiate life-course persistent and adolescence-limited antisocial pathways among males and females, „Development and Psychopathology" 13 , s. $355-375$.

Moffitt T.E., Terrie E. (2010), A developmental model of life-course-persistent offending, [w:] F.T. Cullen, P. Wilcox (red.), Encyclopedia of criminological theory, SAGE Publications, Inc., Thousand Oaks; dostępne online: https://study.sagepub.com/system/files/Moffitt,_Terrie_E._A_Developmental_Model_of_Life-Course-Persistent_Offending.pdf (data dostępu: 27.07 .2015 ).

Muszyńska I. (1976), Ōdczucie przez skazane dolegliwości kary pozbawienia wolności, „Studia Kryminologiczne, Kryminalistyczne i Penitencjarne" V, s. 362-363.

Nowak U. (2009), Dom Matki i Dziecka w Krzywańcu, [w:] I. Dybalska (red.), Kobieta w więzieniu - polski system penitencjarny wobec kobiet w latach 1998-2008, IRSS, Warszawa, s. 236-242.

Pospiszyl K. (1978), Psychologia kobiety, PWN, Warszawa, s. 236-242.

Pruchnik M. (2016), Uzależnienie od alkoholu i terapia kobiet, [w:] B. Jankowiak, A. Matysiak-Błaszczyk (red.), Kontrowersje wokół socjalizacji dziewcząt $i$ kobiet, Wydawnictwo Naukowe UAM, Poznań, s. 331-349.

Reczek H. (2009), Oddziaływania wychowawcze, realizowane w stosunku do osadzonych matek w Domu dla Matki i Dziecka przy Zakładzie Karnym nr 1 w Grudziądzu, [w:] I. Dybalska (red.), Kobieta w więzieniu - polski system penitencjarny wobec kobiet w latach 1998-2008, IRSS, Warszawa, s. 225-231.

Skafiriak B. (2016), Próba prezentacji konkluzji na temat więziennego macierzyństwa w dyskursie naukowym pedagogiki socjalizacyjnej Profesora Jerzego Modrzewskiego, [w:] A. Matysiak-Błaszczyk, E. Włodarczyk (red.), Pedagogika w społeczeństwie - społeczeństwo w pedagogice. Księga Jubileuszowa poświęcona Profesorowi Jerzemu Modrzewskiemu w 70. rocznicę urodzin, Wydawnictwo Naukowe UAM, Poznań, s. 417-436.

Skorny Z. (1987), Proces socjalizacji dzieci i młodzieży, Wydawnictwo Szkolne i Pedagogiczne, Warszawa.

Szcześniak E. (2016), Więźniowie uzależnieni od środków psychoaktywnych, [w:] M. Ciosek, B. Pastwa-Wojciechowska (red.), Psychologia penitencjarna, Wydawnictwo Naukowe PWN, Warszawa, s. 211-217.

Wesołowska-Krzysztofek I. (1996), Wpływ kontaktów z dziećmi na deprywację niektórych potrzeb u osadzonych kobiet, [w:] B. Hołyst, S. Redo (red.), Problemy więziennictwa w progu XXI wieku, Centralny Zarząd Służby Więziennej, Warszawa, s. 470-480.

Zalikowska I. (2009), Terapia, resocjalizacja i readaptacja społeczna skazanych kobiet uzależnionych od alkoholu, [w:] I. Dybalska (red.), Kobieta w więzieniu - polski system penitencjarny wobec kobiet w latach 1998-2008, IRSS, Warszawa, s. 187-198.

Znaniecki F. (1973), Socjologia wychowania, PWN, Warszawa.

\section{Abstract}

The motherhood of women deprived of their liberty is an important social problem, as it affects not only the prisoner herself, but also her children and the whole family, and well as the mother's functioning in a prison. This problem is particularly difficult, as it affects not only prisoners who are mothers but also mothers addicted to alcohol. In this situation, the number of factors affecting the child's development and the challenges posed by the resocialization facility increases. The way in which help is provided in prisons should take into account both the welfare of the mother and of the child. The results of the conducted research indicate that contact with psychoactive substances has a different effect on 
women than on men, and that there are gender differences in the consequences of using and abusing psychoactive substances. Problems related to alcohol abuse are common among women deprived of their liberty and addicts of convicted mothers are increasing in the population of criminal women and girls. The basic goals of employees of Mother and Child Homes and Shelters is to teach women, who are in a situation of active motherhood at the time of imprisonment, the skills connected with the social role of the mother, both under the condition of social isolation and after release. It is also important to ensure their children's safety and to provide conditions which allow their psychosocial and physical development, taking into account the limitations related to the specificity of being in a closed facility.

Keywords: prison, motherhood, addiction, forms of help and support 